\title{
On Science and Civilisation in China
}

\author{
Shellen $W u$
}

This essay is the first part of a series on classic texts that have come to be seen as landmark achievements in their fields. The first essay revisited Noam Chomsky's Aspects of the Theory of Syntax.

$\mathrm{S}$ OY SAUCE Is described in the Encyclopedia Britannica as "a salty brown liquid ... produced from crushed soybeans and wheat that undergo yeast fermentation in salt water for six months to a year or more; it is a ubiquitous ingredient in Asian cooking." ${ }^{1}$ Further references point readers to discussions on the soybean as an agricultural crop, the fermentation process, and the nitrogen cycle. If one's curiosity were piqued but not fully satisfied by this explanation, a series of questions come to mind. When and where was soy sauce invented? What are the other products arising from the yeast fermentation process? How does fermentation figure in the history of Asian food science?

Enter the series Science and Civilisation in China $(S C C)$. Since the publication of the first volume in 1954, the series has become the definitive account of Chinese achievements in science and technology. On the shelves of a library, the series lines up in a comforting bulwark of hefty black-spined tomes. Pull out any volume and one can immediately embark on a delightful excursion into the origins and development of a field of science and technology in China.

For those seeking more information on soy sauce, an entire volume is devoted to fermentation and food science, which is presented as a subcategory of biology and biological technology. ${ }^{2}$ Instead of a few scant paragraphs in an encyclopedia, the fermentation volume devotes almost eighty pages to soybean processing, beginning with a lengthy explanation of the soybean as one of the five staple grains in ancient China. The soybean itself is not readily digestible in its unprocessed form. This was a fact well understood by the ancient Chinese, who recognized the health hazards associated with subsisting on soybean for extended periods. During the Han dynasty (206 BCE-220 $\mathrm{CE}$ ), new processing methods were discovered to convert soybeans into more nutritious and palatable foods. Among the new foods developed was tofu, now seen as one of Chi- na's major contributions to world cuisine. Other similarly detailed sections in this volume examine the history and development of alcohol fermentation, tea processing, and food preservation technologies.

The food science volume, published in 2001, is representative of the general approach throughout the series. Author Huang Hsing-Tsung surveys the written evidence in ancient works such as the Bo Wu Zhi ("Records of Diverse Matters," ca. $190 \mathrm{CE}$ ), the materia medica literature, and the writings of the Chinese literati throughout the premodern and medieval periods. His account also incorporates archaeological findings, including illustrations from tomb engravings and photographs of agricultural methods from the modern period-in this case, tofu presses found in a village during the 1980s. Huang even experiments with food processing techniques from the historical record, describing his efforts to coagulate soymilk. These varied approaches make for an exhaustive and comprehensive historical examination of Chinese food science.

In a brief preface, Huang describes how he came to write the volume. In the fall of 1942, he spent several months taking refuge from the war in his ancestral village of Hothang, located in the coastal province of Fujian in southeastern China. Huang had recently graduated with a bachelor's degree in chemistry from the University of Hong Kong and was awaiting bureaucratic approval to become a research technician for the Chinese Industrial Cooperatives, an organization supported by expatriated Westerners that promoted technological advancement in China. With little else to occupy his time in Hothang, Huang became interested in the local food trade. He began spending hours observing all the different food vendors, from the tofu and noodle makers to the workers at the soy sauce shop. In April 1943, not long after Huang's period of enforced rustication came to an end, he received a letter from a British biochemist. Joseph Needham had arrived from England to set up a new Sino-British Science Cooperation Office in the wartime capital of Chongqing, a sprawling city in the southwestern province of Sichuan. Needham offered Huang a position working for him as a secretary and interpreter. 
In the years that followed, Huang traveled with Needham on his expeditions throughout the southwest and northwest regions of China, which were not yet occupied by the Japanese. On one such trip, he encountered the scientist Shih Sheng-Han, who had received his $\mathrm{PhD}$ from Imperial College in London. Shih not only spoke English fluently, but also had a commanding knowledge of the Chinese classics and references to Chinese food processes in the written record. Huang's discussions with Shih, Needham, and other scientists during the war made a deep and lasting impression. Decades later, he enthusiastically accepted Needham's invitation to collaborate on the food science volume. In 1984, Huang was the program director for biochemistry at the National Science Foundation in Washington, DC. What began in the mid-1980s as a weekend and holiday project became Huang's sole focus after his retirement in 1990.

A LTHOUGH THE OTHER authors in the series did not share Huang's early working relationship with Needham, their contributions demonstrate a similarly erudite approach. In the volume on mining, Peter Golas discusses archaeological evidence for timbered mineshaft technology from the Warring States period (475-221 BCE); he also provides photographs of early twentieth-century Chinese mines. ${ }^{3}$ In another volume examining agriculture-not to be confused with a separate volume on agro-industry and forestry ${ }^{4}-$ Francesca Bray presents agriculture as "par excellence the technological system that mediates between nature and society." Her contribution includes a meticulously documented account of the agricultural regions, the crop and field systems, and agricultural implements and techniques used throughout China.

Before these volumes were spun out into stand-alone works, SCC more closely reflected the intellectual ambitions of its founder. Needham was born in London in 1900, the only child of a volatile Edwardian marriage. By the time he traveled to a war-torn China in 1942 as the director of the Sino-British Science Cooperation Office, he was already one of the world's leading biochemists, an elected fellow at Caius College at Cambridge University, and the author of several groundbreaking works on embryology and morphogenesis.

The story of how Needham came to embark on an all-consuming study of Chinese science and technology has all the ingredients of a soap opera. In 1937, Needham fell in love with a Chinese graduate student from Nanjing, $\mathrm{Lu}$ Gwei-djen. At the time, Needham had been married to a fellow biochemist, Dorothy Moyle, for more than a decade. Needham and Moyle would later share the honor of becoming the first married couple to be elected to the Royal Society. Needham carried on a decades-long relationship with $\mathrm{Lu}$, eventually marrying her after Moyle's death in 1989. Moyle apparently did not object to their relationship, and for many years Lu lived in a house in Cambridge, just a few steps away from their marital home.

According to Simon Winchester's biography of Needham, it was this romance that set Needham on the path to China. ${ }^{5}$ Lu's father, a pharmacist living in Nanjing, had long fostered in her the belief that China had made great unacknowledged contributions to science and technology. Encouraged by Lu, Needham began learning Chinese. The vicarious influence of Lu's father made a deep enough impression that Needham later dedicated the first volume of SCC to "Lu Shih-Kuo, merchant-apothecary in the city of Nanjing."

Needham's relationship with Lu may have sparked his initial interest in China, but it was not the only factor that spurred Needham's fascination with Chinese science. By the time Needham encountered Lu, the firmly left-wing political sympathies he harbored throughout his life were already well established. In 1931, Needham had been involved in organizing the Second International Congress of the History of Science and Technology, which was held in London. Among the attendees was a Soviet delegation led by the Bolshevik revolutionary and Marxist theoretician Nikolai Bukharin. One of the most notable contributions during the conference was a paper by a Soviet physicist, Boris Hessen, entitled "The Social and Economic Roots of Newton's Principia." Hessen's ideas made a lasting impression on Needham and were the inspiration for his subsequent research on the relationship between science and society. ${ }^{7}$ Needham's Marxist leanings led him to critique the Western-centric views of scientific history that were then prevalent. Over time, he came to view the development of science as foundational to any and all civilizations. Needham's work on Chinese scientific history became the vehicle by which he expressed his broader ideas on science and technology.

In 1942, Needham eagerly accepted the opportunity to travel to China under the auspices of the Royal Society and the Foreign Office. He was tasked with overseeing a new department that was to aid Chinese scientists during the war. Starting in 1937, the Japanese invasion had led a number of Chinese universities and scientists to abandon their laboratories and retreat to the southwest. In exile, the researchers attempted to continue their work despite material shortages and all manner of hardships.

Needham applied for and was awarded the position of director of the Sino-British Science Cooperation Office in Chongqing, which he held from 1942 to 1946. He eventually brought on $\mathrm{Lu}$ as an employee, provoking complaints of nepotism from disgruntled colleagues. The biologist and ethnomusicologist Laurence Picken was sufficiently outraged to pen a memorandum to a member of the British Council in London, accusing Needham of misusing government funding to pay the wages of his mistress. ${ }^{8}$

Accompanied by Huang, Needham embarked on eleven expeditions from Chongqing to scientific outposts around 
the country. These journeys took him from Fujian on China's southeastern coast, barely managing to stay ahead of a Japanese offensive that would have considered him a prized prisoner of war, to Xinjiang in the far west, where he visited the famed Buddhist caves in Dunhuang. Many of the photographs published in the first volumes of $S C C$ were taken during these wartime expeditions. Needham's expeditions also allowed him to build lasting relationships with a variety of figures, including the Communist Party leader Zhou Enlai, who later served as the premier of the People's Republic of China.

On one of his trips in 1944, Needham met the Harvard-trained meteorologist $\mathrm{Zhu}$ Kezhen, who was then president of Zhejiang University. The taciturn Zhu left little impression on Needham, but the opposite was apparently true for Zhu, who later learned of Needham's plan to write a history of Chinese contributions to science. After the Communist takeover in 1949, Zhu was appointed vice-president of a newly reorganized Chinese Academy of Sciences. During the early 1950s, Needham received a surprise shipment of wooden crates full of rare books and papers dispatched by Zhu to aid his project. ${ }^{9}$ In this respect, Zhu was far from alone. Numerous other Chinese scientists were similarly eager to help. The war fostered nationalistic feelings among Chinese scientists and had already begun to spark renewed interest in the country's scientific history by the time Needham arrived. The conversations Needham had with Chinese scientists and the network he built during his four years in the country provided the material for what he initially envisaged as a book on premodern Chinese scientific and technological achievements. It quickly became clear to Needham that a single volume would not suffice. To accommodate the abundance of materials he had gathered, he planned seven volumes to be published over the course of a decade.

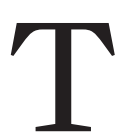

HE APPEARANCE OF the first volume of $S C C$ in 1954 was a milestone, not only for Needham, but also for the history of science in China. Indeed, the role played by SCC in launching this field of inquiry should be seen as one of its most significant and lasting contributions. Prior to its publication, Needham's reputation had been tarnished by his participation in an international commission investigating Chinese allegations that the US had used biological weapons during the Korean War. The commission sided with China, and Needham earned the opprobrium of Western scientists and government officials for his perceived political naivete. Fortunately for Needham and his project, the scandal had no impact on the initial reviews of $S C C$, which was widely hailed as a work of genius. Needham was compared to a modern Erasmus.

The first volume of SCC introduces the study, the second provides a history of Chinese scientific thought by examining the major schools of Chinese philosophy and their openness to scientific methodology, and the third pro- vides a history of Chinese mathematics and astronomy. By the time Needham had reached the substantive volumes, even the seven-volume plan appeared insufficient for the mountains of materials he had begun to unearth. The fourth volume, dedicated to physics and physical technology, was expanded to a three-part survey covering physics, mechanical engineering, and civil engineering. The latter was paired with a study of sailing and navigation. The fifth volume on chemistry and chemical technology ballooned into thirteen parts, the last of which covered mining. The sixth volume on biology and biological technology is now up to part six. A seventh volume, currently divided into two parts, is focused on language and logic.

When the first volume of $S C C$ was published in 1954, Needham was one of the few Western scientists able to speak and read Chinese. At the time, Chinese scientific and technological accomplishments were largely unknown in the West, even among scientists. This situation was not helped by the Chinese Communist takeover in 1949 and the creation of a single-party state in mainland China, which left the country diplomatically isolated. Needham subsequently became one of the most important conduits between Chinese science and the international scientific community. When the first volumes of $S C C$ were being published, the prospect of a complete break between Socialist science and the West appeared a distinct possibility.

The rapid expansion of the $S C C$ project meant that, in later years, the series was no longer the intellectual progeny of one man. Over time, the universal praise for the early volumes gradually gave way to a more measured assessment. The consensus among historians of science also began shifting in the decades following the appearance of $S C C$ and it became less tenable to assume, for example, that there was only a single scientific revolution in Europe, and none elsewhere. But the series was most frequently criticized for its civilizational approach to the history of science, which implied that modern science was an exclusively Western achievement.

In his introduction to the first volume, Needham described the guiding principles and lines of inquiry for the series. On the opening page, he posed the question: "Why should the science of China have remained, broadly speaking, on a level continuously empirical, and restricted to theories of primitive or medieval type?" On the following page, he rephrased the question in broader terms:

What were the inhibiting factors in Chinese civilization which prevented a rise of modern science in Asia analogous to that which took place in Europe from the 16th century onwards, and which proved one of the basic factors in the moulding of modern world order? ${ }^{10}$

In his 1969 work, The Grand Titration: Science and Society in East and West, Needham offered the most famous iteration of this question: "Why did modern science, the 
mathematization of hypotheses about Nature, with all its implications for advanced technology, take its meteoric rise only [emphasis original] in the West, at the time of Galileo?"11 By framing the question in these terms, Needham elevated "What went wrong?" as the most important question in modern Chinese history. The Needham Question, as it is often referred to, has influenced more than a generation of studies on Chinese science.

In subsequent volumes, Needham catalogued many innovations, including China's four great inventions-the compass, gunpowder, paper, and printing-which had all previously been considered quintessentially Western developments. Along with the help of Chinese scientists such as Zhu, who recognized in Needham a researcher in a unique position to aid the fledgling Chinese scientific community, he was able to bring unprecedented attention to early developments in Chinese science and technology. Despite all the impressive feats of engineering and innovation, at some point, Needham believed, it all came to a crashing halt. This viewpoint colored the work of science historians, both in Europe and Asia, for many years.

In Asia in the Making of Europe, Donald Lach noted a tendency among sixteenth-century writers to assume that, "Asia no longer [had] anything to contribute to Europe other than porcelains, lacquers, and textiles." ${ }^{12}$ Like Needham, Lach saw the sixteenth century as the cutoff point when Chinese science and technology stalled, just as it was taking off in Europe. Consider also the argument made by Michael Adas in Machines as the Measure of Men that technological superiority influenced European views of the other and fueled Western expansionism..$^{13}$ For Lach, Asia's significance lies not in the innovations it introduced to Europe, but in its role as the other, stimulating a growing sense of identity among Europeans. Adas makes a similar claim for technological innovations in Europe shaping European perceptions of Asia. In these accounts, Asia, and China in particular, are seen as little more than passive onlookers.

A more nuanced account has been offered by sinologists, such as Nathan Sivin, who have sought to reevaluate the confrontation between Chinese and Western thought. In particular, Sivin has focused on the reception and transmission of Copernicanism in China during the seventeenth and eighteenth centuries. ${ }^{14}$ According to Sivin, the Confucian elite, who were the first and most important recipients of Jesuit scientific knowledge, remained largely loyal to the indigenous worldview while also adapting European technical innovations they acknowledged as superior. Rather than being entirely closed off to Western science, the Jesuit influence led the educated elite to reexamine Chinese traditional science. Sivin argues that through the Jesuit filter, "the character of early modern science was concealed from Chinese scientists, who depended on the Jesuit writings." ${ }^{15}$ For more than a century and a half after Copernicus first described the heliocentric solar system,
Jesuit missionaries continued teaching a geocentric model and misrepresenting the work of Copernicus in ways that were garbled and contradictory. Supplied with fragmentary and incorrect information, Chinese scholars in astronomy and mathematics were understandably unable to puzzle out the Copernican revolution. In this reading, the European visitors are more at fault than closed-mindedness among the Chinese elites.

$\mathrm{I}$ N THE 1950s, SCC had begun as a revolutionary work by a brilliant scientist that forced the world to acknowledge early Chinese scientific and technological achievements. As the number of volumes expanded, Needham's original vision became increasingly strained. In later years, he and Lu strenuously resisted outside challenges to his project and its aims, even while the $S C C$ expanded in scope and became institutionalized at a research center named after Needham. Toward the end of Needham's life, the shortcomings of his increasingly anachronistic approach to the history of science began to affect perceptions of $S C C$.

The first volume of $S C C$, which outlined the vision and guiding principles for the series, now seems the most dated. Despite these limitations and the shifting consensus among science historians during the intervening decades, the broader accomplishments of $S C C$ have not been diminished. The substantive volumes stand on their own merits as great achievements. Huang's volume on food science was published six years after Needham's death in 1995. The front page includes an inscription from the preface of the opening volume:

Certain it is that no people or group of peoples has had a monopoly in contributing to the development of Science. Their achievements should be mutually recognized and freely celebrated with the joined hands of universal brotherhood.

This passage articulates the most important goal of the series: to challenge historians of science in their focus on the West to the exclusion of other major world civilizations. Judged on these terms, SCC has exceeded even Needham's expectations.

\section{Shellen Wu is Associate Professor of History at the} University of Tennessee, Knoxville.

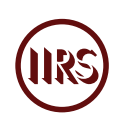

1. "Soy Sauce," Encyclopedia Britannica.

2. H. T. Huang, Science and Civilisation in China: Vol. 6, Biology and Biological Technology, Part V, Fermentations and Food Science (Cambridge, UK: Cambridge University Press, 2000). 
3. Peter Golas, Science and Civilisation in China: Vol.5, Chemistry and Chemical Technology, Part XIII, Mining (Cambridge, UK: Cambridge University Press, 1999), 11-12.

4. Francesca Bray, Science and Civilisation in China: Vol. 6, Biology and Biological Technology, Part II, Agriculture (Cambridge, UK: Cambridge University Press, 1984).

5. Simon Winchester, The Man Who Loved China: The Fantastic Story of the Eccentric Scientist Who Unlocked the Mysteries of the Middle Kingdom (New York: HarperCollins, 2008). For the writing of this biography, Winchester was given free access to almost all of Needham's papers and correspondence.

6. For an English translation see Boris Hessen, "The Social and Economic Roots of Newton's Principia," in Boris Hessen and Henryk Grossmann, Boston Studies in the Philosophy of Science: The Social and Economic Roots of the Scientific Revolution, ed. Gideon Freudenthal and Peter McLaughlin (New York: Springer, 2009), 41-101.

7. Francesca Bray, "How Blind Is Love?: Simon Winchester's The Man Who Loved China," Technology and Culture 51, no. 3 (2010): 587, doi:10.1353/tech.2010.0015.
8. Winchester, Man Who Loved China, 160-61.

9. Winchester, Man Who Loved China, 175-77.

10. Joseph Needham, Science and Civilisation in China: Vol. 1, Introductory Orientations (Cambridge, UK: Cambridge University Press, 1954), 3-4.

11. Joseph Needham, The Grand Titration: Science and Society in East and West (Toronto: University of Toronto Press, 1969), 16.

12. Donald Lach, Asia in the Making of Europe: Vol. 2, A Century of Wonder (Chicago: University of Chicago Press, 1977), 405.

13. Michael Adas, Machines as the Measure of Men: Science, Technology, and Ideologies of Western Dominance (Ithaca: Cornell University Press, 2015).

14. Nathan Sivin, "Copernicus in China, or, Good Intentions Gone Astray," in Science in Ancient China: Researches and Reflections (Aldershot: Variorum, 1995).

15. Sivin, “Copernicus in China," 2.

DOI: $10.37282 / 991819.21 .38$ 